\title{
Perbandingan Ekuitas Merek Produk Kosmetik Asing Orea Dengan Kosmetik Lokal
}

(Studi Pada Merek Etude House Dan Merek Wardah)

\author{
Maretta Edgina Damayanti, Berta Bekti Retnowati \\ email: berta@unika.ac.id
}

Fakultas Ekonomi dan Bisnis Unika Soegijapranata

\begin{abstract}
Brand equity became important for a product because it referred to a set of brand assets and liabilities related to a brand, its name and its symbol, which add or subtract the value provided by a good or service to the company or its customers. Departing from this understanding, this study aimed to conduct empirical differences or comparative studies on local cosmetic products represented by local brand the Wardah and South Korea cosmetic product represented by Etude House. The data required in this study was obtained through interviews using a questionnaire. Interviews were conducted to students at four Universities in Semarang, namely Soegijapranata Chatolic University, Dian Nuswantoro University, Diponegoro University, and Semarang State University. Data analysis for the purpose of this study was conducted using the Mann Whitney Comparative Test (U-test). The results showed that brand awareness, brand association, perceived quality of Wardah and Etude House cosmetics were significantly different, while the brand loyalty to Wardah and Etude House cosmetics brand was the same.
\end{abstract}

Keywords: brand awareness, brand association, perceived quality, brand loyalty

\section{PENDAHULUAN}

Menurut Kertajaya (2010) merek (brand) berperan sebagai value indicator bagi seluruh stake holder perusahaan (pelanggan, karyawan, serta investor). Pelanggan lebih memilih produk dengan merek yang lebih terkenal. Pada jaman globalisasi saat ini, perusahaan harus menyiapkan kekuatan dan keunggulan untuk memasarkan produk nya sehingga dapat menarik perhatian konsumen. Salah satu kekuatan dan keunggulan perusahaan untuk menghadapi persaingan global adalah dengan mempertahankan merek. Semakin tinggi ekuitas merek, maka semakin tinggi pula value yang diberikan kepada konsumen sehingga, perusahaan yang mempertahankan mereknya akan berjaya (Santoso dan Resdianto, 2007). 
Dalam penelitian yang dilakukan oleh Mourad (2011) menyatakan bahwa untuk mendominasi kesadaran konsumen terhadap suatu merek, maka perusahaan harus memperkuat mereknya sehingga eksis di pasar dan dikenal oleh banyak orang. Jika suatu merek memiliki ekuitas merek yang kuat, maka dapat meningkatkan minat pembelian terhadap barang tersebut. Sehingga, ekuitas merek memiliki hubungan langsung dengan jumlah penjualan (Jung dan Sung, 2008).

Survei yang dilakukan di JakPat pada tahun 2015 dengan total keseluruhan responden adalah 548 responden. Menurut hasil survey, minat masyarakat Indonesia terhadap kosmetik merek Korea ditunjukkan dari survei sebanyak 18,98\% responden memilih produk kosmetik buatan Korea setelah kosmetik Indonesia. Terbanyak memilih merek lokal Indonesia 49,64\%. Merek yang lain berasal dari USA 11,68\%, Jepang 8,76\%, China 2,37\% dan lain-lain 8,76\% ( www.jakpat.net, JakPat 2015). Produk kosmetik Korea pun juga memiliki beberapa merek yang dijual di Indonesia. Hanya beberapa merek yang disukai, dikonsumsi, dan mungkin bahkan mereknya menjadi top of mind konsumen. Survei di JakPat yang dikutip pada halaman artikel mix.co.id pada tahun 2016, terdapat enam brand Korea yang dikenal dan diminati wanita dan pria Indonesia berusia 16-35 tahun. Hasil survei online tersebut diikuti oleh sebanyak 274 responden dimana hasil dari survei tersebut yaitu sebanyak 55,13\% responden mengaku pernah menggunakan brand kosmetik Korea. Sebanyak 71,17\% pernah membeli dan menggunakan merek Etude House. Hal ini menunjukkan bahwa walaupun sudah banyak produk kosmetik Korea lain yang masuk ke pasar tanah air, Etude House masih memimpin pasar kosmetik di Indonesia.

Penelitian tentang ekuitas merek yang lain dilakukan oleh Stocchi dan Fuller (2017), yang membandingkan kekuatan ekuitas merek yang diperluas pada sejauh mana kesadaran merek dan citra merek berkontribusi dalam kecenderungan untuk pembelian, untuk segmen konsumen yang berbeda dan dua pasar yang berbeda (soft drink dan perbankan). Dari penelitian tersebut menyatakan bahwa image dari sebuah merek dapat mempengaruhi tingkat 
kesetiaan konsumen terhadap merek tersebut penemuan yang kedua yaitu kekuatan brand equity dari produk soft drink lebih kuat dari pada perbankan. Penelitian ini juga memberikan arahan bahwa di penelitian selanjutnya dapat memperluas kategori produk dan negara. Kedua, dalam penelitian ini menggunakan konsep CBBE (Customer Based Brand Equity) dimana konsep ini terlalu sederhana. Penelitian selanjutnya dapat menggunakan konsep yang lebih luas. Ketiga, pada penelitian selanjutnya dapat menambahkan variabel lain. Peneliti tertarik untuk melakukan perbandingan ekuitas merek antara dua produk kosmetik dengan merek Etude House dan merek Wardah.

\section{Masalah dan Tujuan Penelitian}

Masalah penelitian ini adalah bagaimana perbandingan brand equity antara kosmetik merek Etude House dengan merek Wardah yang mencakup keempat dimensi brand equtity yaitu brand awareness, brand association, perceived quality dan brand loyalty? Tujuan penelitian ini ingin mengetahui perbandingan brand equity (ekuitas merek) produk kosmetik Korea merek Etude House dengan kosmetik lokal merek Wardah dari keempat dimensi tersebut.

\section{LANDASAN TEORI}

\section{Ekuitas Merek}

Menurut David A. Aaker (1997) dalam jurnal Suyadi dan Fannani (2017), ekuitas merek adalah seperangkat aset dan liabilitas merek yang berkaitan dengan suatu merek, nama dan simbolnya, yang menambah atau mengurangi nilai yang diberikan oleh sebuah barang atau jasa kepada perusahaan atau para pelanggan perusahaan.

Pendapat lain tentang ekuitas merek dikemukakan oleh Simamora, dalam Darmawan, Syarifah, dan Asnawati (2016), bahwa ekuitas merek adalah kekuatan merek atau kesaktian merek yang memberikan nilai pada konsumen. Menurut Neumeir (2006) dalam jurnal yang ditulis oleh Giroux et al. (2017), 
ekuitas merek merupakan salah satu aset yang paling penting dan paling menguntungkan bagi perusahaan. Ekuitas merek merupakan penyusunan perseptual, persepsi konsumen, yang memberi nilai tambah untuk produk bermerek (Rodrigues 2016), dibandingkan dengan produk dalam kategori yang sama namun tidak bermerek (Veloutsou et al. 2017).

Berdasarkan Aaker (1991) dan Keller (1993) dalam jurnal yang ditulis oleh Loureiro (2017), ekuitas merek (brand equity) terdiri dari empat elemen inti yaitu kesadaran merek (brand awareness), asosiasi merek (brand association), persepsi kualitas (perceived quality), loyalitas merek (brand loyalty). Dari beberapa definisi dan pemahaman tentang ekuitas merek yang telah disebutkan, peneliti merumuskan bahwa ekuitas merek merupakan seperangkat aset yang dimiliki oleh perusahaan dalam bentuk nama dan simbol, namun dapat menjadi aset yang paling penting bagi perusahaan yang nantinya dapat memberikan nilai tambah.

\section{Kesadaran Merek (Brand Awareness)}

Dalam jurnal yang ditulis Loureiro (2017), menurut Keller, kesadaran merek mencerminkan pentingnya sebuah merek dalam benak atau pikiran konsumen yang berkaitan dengan kemampuan konsumen mengenali atau mengingat merek sebagai anggota kategori produk tertentu. Kesadaran merek (brand awareness) merupakan tingkat yang paling sederhana atau titik awal dari proses pengenalan merek ke konsumen (Romaniuk, Wight, and Faulkner 2016).

Menurut Aaker (dalam Rangkuti, 2002), kesadaran merek (brand awareness) artinya adalah kesanggupan seorang calon pembeli untuk mengenali atau mengingat kembali suatu merek. Tingkatan kesadaran merek secara berurutan dari yang rendah sampai tinggi dapat dijelaskan sebagai berikut: Unware of brand (tidak menyadari merek) dimana konsumen tidak mengenali merek sama sekali walaupun sudah dilakukan pengingatan kembali akan merek melalui bantuan (aided recall); Brand Recognition (pengenalan 
merek), dimana konsumen mulai mengenali merek terutama saat melihat merek tersebut pertama kali, saat akan membeli produk, atau diberi bantuan dalam mengingat merek (aided recall). Brand Recall (pengingat kembali terhadap merek) dimana konsumen mengingat kembali merek dalam kategori produk tertentu tanpa harus diberi bantuan untuk mengingat kembali (unaided recall). Dan Top of Mind (puncak pikiran) dimana konsumen ditanya mengenai merek untuk suatu kategori produk tertentu, konsumen tersebut langsung menjawab merek tententu tanpa berpikir panjang dan selalu menyebutkan merek tersebut (Romaniuk, Wight, and Faulkner 2016).

Dari beberapa pemahaman tersebut, maka penulis merumuskan bahwa kesadaran merek (brand awareness) merupakan titik awal dimana konsumen mengenal sebuah merek dan seberapa jauh merek tersebut ada di benak konsumen sehingga, ketika konsumen diminta menyebut merek dari suatu kategori produk tertentu, konsumen tersebut dapat menyebutkan nama merek dengan atau tanpa bantuan.

\section{Asosiasi Merek (Brand Association)}

Menurut Aaker (1997), dalam jurnal Darmawan, Syarifah, dan Asnawati (2016), asosiasi merek adalah segala hal yang berkaitan dengan ingatan suatu merek dan asosiasi tidak hanya eksis namun memiliki tingkat kekuatan. Berbagai asosiasi yang diingat konsumen akan membentuk brand image di benak konsumen. Asosiasi merek berhubungan dengan atribut-atribut yang melambangkan produk atau jasa. Asosiasi merek dapat dibedakan berdasarkan (Stocchi and Fuller 2017): meliputi Atribut produk atau fitur secara visual misalnya seperti harga, penampilan produk, bentuk produk, dan lain-lain. Atribut yang tidak berwujud misalnya seperti, manfaat yang dapat dirasakan oleh konsumen dan pengalaman yang dirasakan konsumen ketika menggunakan produk. Dan sikap dan evaluasi merek secara keseluruhan. Dari penjelasan tersebut, peneliti merumuskan bahwa asosiasi merek (brand 
association) merupakan hal-hal yang berkaitan dengan ingatan akan suatu merek berdasarkan evaluasi secara keseluruhan akan suatu merek.

\section{Persepsi Kualitas (Perceived Quality)}

Pengertian persepsi kualitas menurut Aaker (dalam Rangkuti, 2002) adalah persepsi pelanggan terhadap keseluruhan kualitas atau keunggulan suatu produk atau jasa layanan berkaitan dengan maksud yang diharapkan. Menurut Durianto et al (2001), manfaat yang diberikan perceived quality adalah: menjadi alasan konsumen untuk membeli produk yang ditawarkan; diferensiasi dan pemosisian produk. Konsumen ingin memilih aspek tertentu sebagai keunikan dan kelebihan produk. Aspek yang memiliki perceived quality yang tinggi yang dapat dipilih konsumen. Harga optimum. Produk yang memiliki perceived quality yang tinggi memiliki alasan untuk menetapkan harga yang tinggi. Minat saluran distribusi meningkat karena para pengecer, distributor, lebih mudah menerima produk yang perceived quality nya tinggi. Dan perluasan merek (brand extension). Sebuah merek yang memiliki perceived quality yang tinggi dapat digunakan sebagai merek produk lain yang berbeda. Menurut Durianto et al (2001) dalam jurnal yang ditulis oleh Permana dan Haryanto (2014), dimensi-dimensi yang mempengaruhi persepsi kualitas adalah: serviceability, durability, reliability, features, comformance with specifications, fit and fitness.

\section{Loyalitas Merek (Brand Loyalty)}

Oliver (1991) dalam Molinillo et al. (2017) mendefinisikan loyalitas merek sebagai "komitmen yang sangat dipegang teguh untuk membeli kembali produk atau jasa yang disukai secara konsisten di masa depan, sehingga menyebabkan pembelian secara berulang kali terhadap merek (brand) yang sama, terlepas dari pengaruh situasional dan upaya pemasaran yang memiliki dapat menyebabkan potensi beralihnya ke merek lain.” 
Menurut Rangkuti (2002), merek adalah ukuran dari kesetiaan konsumen terhadap suatu merek. Loyalitas merek merupakan inti dari brand equity, karena hal ini merupakan satu ukuran keterkaitan seorang pelanggan pada sebuah merek. Loyalitas merek memiliki beberapa tingkatan. Tidak loyal, berpindah-pindah merek. Pembeli yang puas dengan produk yang digunakan atau minimal tidak merasa kecewa terhadap merek. Pembeli yang puas namun memikul biaya peralihan (switching cost). Pelanggan yang puas atau bersifat kebiasaan. Pelanggan tingkat pertama atau committed dapat dikatakan sebagai pelanggan yang setia. Loyalitas merek dapat diukur melalui: Behaviour Measure, Measuring Switch Cost, Measuring Satisfaction, Measuring Liking Brand dan Measuring Commitment.

Berdasarkan pemahaman yang telah dijelaskan, peneliti merumuskan bahwa loyalitas merek merupakan tingkat ukuran kesetiaan konsumen terhadap suatu produk yang ada di benak masing-masing konsumen. Tingkat kesetiaan dari satu konsumen ke konsumen lain berbeda-beda. Tingkat kesetiaan atau loyalitas dapat diukur dari perilaku kebiasaan konsumen dalam mengkonsumsi merek produk yang sama secara terus menerus. Seorang konsumen yang loyal akan melakukan pembelian secara berulang kali suatu produk yang disukai sampai tingkat dimana ia rela membayar lebih untuk mendapatkan merek produk yang sama.

\section{Kerangka Penelitian}

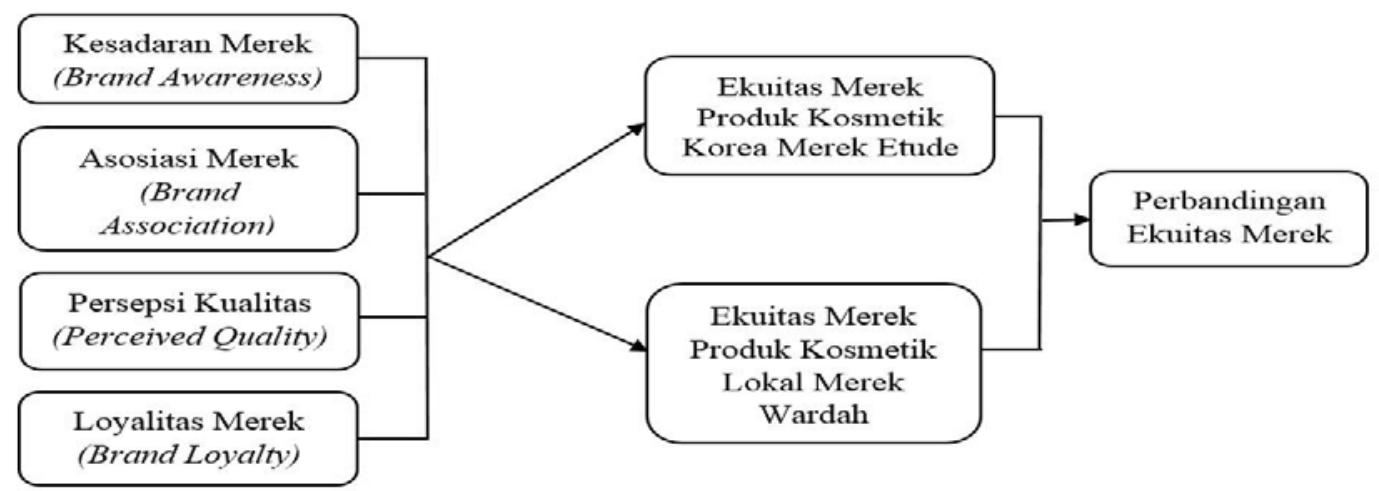

Gambar 1. Kerangka Pikir 
Ekuitas merek merupakan seperangkat aset yang menjadi salah satu ciri khas dari suatu produk atau perusahaan tertentu. Masing-masing konsumen tentu memiliki persepsi tentang suatu merek. Seberapa dalam konsep merek di benak masing-masing konsumen tentu berbeda dari satu konsumen ke konsumen yang lain. Ekuitas merek memiliki empat elemen yaitu: Kesadaran merek (brand awareness), Asosiasi merek (brand association), Persepsi kualitas (perceived quality) dan Loyalitas merek (brand loyalty).

Keempat elemen ekuitas merek tersebut menjadi variabel untuk mengukur seberapa kuat ekuitas merek dari masing-masing produk kosmetik di benak konsumen. Hasil pengukuran ekuitas merek produk kosmetik merek Etude House akan dibandingkan dengan produk kosmetik merek Wardah.

\section{Hipotesis Penelitian}

Ho : Kedua merek kosmetik (Wardah dan Etude House) tidak memiliki perbedaan ekuitas merek.

H1 : Kedua merek kosmetik (Wardah dan Etude House) memiliki perbedaan ekuitas merek.

\section{Definisi Operasional Variabel}

Kesadaran merek (brand awareness). Kesadaran merek (brand awareness) adalah kemampuan konsumen untuk mengetahui, mengenali, bahkan mengingat produk kosmetik Etude House atau Wardah ketika konsumen ditanya mengenai merek kosmetik. Pada penelitian ini berdasarkan indikator-indikator yang digunakan yaitu: mengingat produk kosmetik merek (Etude House atau Wardah); mengetahui produk kosmetik merek (Etude House atau Wardah); produk kosmetik merek (Etude House atau Wardah) akan muncul di benak konsumen ketika konsumen mengingat produk kosmetik dan menyadari produk kosmetik merek (Etude House atau Wardah).

Asosiasi merek (brand association). Asosiasi merek (brand association) adalah segala ingatan (memory) konsumen mengenai produk kosmetik Etude House atau 
Wardah. Pada penelitian ini berdasarkan indikator-indikator yang digunakan yaitu: harga produk kosmetik merek (Etude House atau Wardah) terjangkau; bahan-bahan yang digunakan aman dan bebas dari bahan kimia; kemasan menarik; dan kemudahan konsumen dalam mendapat produk kosmetik merek (Etude House atau Wardah).

Persepsi kualitas (perceived quality). Persepsi kualitas (perceived quality) adalah persepsi pelanggan terhadap keseluruhan kualitas produk kosmetik merek Etude House atau Wardah. Pada penelitian ini berdasarkan indikator-indikator yang digunakan yaitu: Hasil pemakaian produk kosmetik merek (Etude House atau Wardah) terasa baik di kulit wajah konsumen; Produk kosmetik merek (Etude House atau Wardah) memiliki banyak variasi jenis produk kosmetik yang lengkap; Manfaat produk kosmetik merek (Etude House atau Wardah) yang dirasakan konsumen sesuai dengan klaim produk; dan Produk kosmetik merek (Etude House atau Wardah) memiliki kualitas yang baik.

Loyalitas merek (brand loyalty). Loyalitas merek (brand loyalty) adalah rasa keterkaitan konsumen terhadap produk kosmetik merek Etude House atau Wardah dan kemungkinan untuk membeli kembali. Pada penelitian ini berdasarkan indikator-indikator yang digunakan yaitu: Membeli produk kosmetik merek (Etude House atau Wardah) kembali; Konsumen merasa puas dengan produk kosmetik merek (Etude House atau Wardah); dan merekomendasikan produk kosmetik merek (Etude House atau Wardah) ke orang lain.

\section{METODE PENELITIAN}

Objek penelitian ini adalah produk kosmetik Korea merek Etude House dengan produk kosmetik lokal merek Wardah. Populasi adalah keseluruhan jumlah yang terdiri atas objek atau subjek yang mempunyai karakteristik dan kualitas tertentu yang ditetapkan oleh peneliti untuk diteliti dan kemudian ditarik kesimpulannya (Sujarweni, 2015). Populasi dari penelitian ini adalah semua pengguna produk kosmetik di empat universitas yang berlokasi di Semarang yaitu 
UNIKA Soegijapranata, Universitas Dian Nuswantoro, Universitas Diponegoro, dan Universitas Negeri Semarang, dimana mahasiswa keempat universitas tersebut memasuki rentang umur pada remaja dan dewasa muda.

Sampel adalah bagian dari sejumlah karakteristik yang dimiliki oleh populasi yang digunakan oleh peneliti (Sujarweni, 2015). Sampel dari penelitian ini adalah pengguna produk kosmetik merek Etude House dan merek Wardah. Jumlah pengguna kosmetik di UNIKA Soegijapranata, Universitas Dian Nuswantoro, Universitas Diponegoro, dan Universitas Negeri Semarang cukuplah banyak sehingga jumlah populasi tidak dapat ditentukan secara pasti. Maka dari itu, pengambilan sample ditentukan dalam batas periode waktu tertentu.

Metode yang digunakan dalam pengambilan sampel dalam penelitian ini adalah non-probability sampling, yaitu teknik pengambilan sampel yang tidak memberi peluang atau kesempatan sama bagi setiap unsur dari populasi untuk dipilih sebagai sampel (Sujarweni, 2015). Teknik yang digunakan dalam penelitian ini yaitu purposive sampling dimana teknik ini merupakan prosedur sampling yang memilih sampel dari orang atau unit yang dijumpai dengan pertimbangan atau kriteria tertentu (Sujarweni, 2015). Sampel dalam penelitian ini harus memenuhi dua kriteria yaitu: Minimal memiliki produk kosmetik merek (Etude House atau Wardah) sebanyak satu produk. Jangka waktu pemakaian produk kosmetik merek (Etude House atau Wardah) minimal selama dua bulan.

\section{Uji Reliabilitas}

Pengujian reliabilitas dilakukan dengan menggunakan Uji Alpha Cronbach dengan kriteria hasil pengujian sebagai berikut. Jika nilai Alpha Cronbach hasil perhitungan > 0,6 maka dapat dikatakan bahwa variabel penelitian adalah reliabel. Jika nilai Alpha Cronbach hasil perhitungan < 0,6 maka dapat dikatakan bahwa variabel penelitian tidak reliabel. Berikut ini hasil uji reliabilitas pada masing-masing variabel penelitian. 
Tabel 1

Hasil Uji Reliabilitas

\begin{tabular}{|l|c|c|}
\hline \multicolumn{1}{|c|}{ Variabel Penelitian } & $\begin{array}{c}\text { Alpha } \\
\text { Cronbach }\end{array}$ & Keterangan \\
\hline Kesadaran Merek (Brand Awareness) & 0,659 & valid \\
\hline Asosiasi Merek (Brand Association) & 0,680 & valid \\
\hline Kualitas Merek (Perceived Quality) & 0,732 & valid \\
\hline Loyalitas Merek (Brand Loyalty) & 0,848 & valid \\
\hline
\end{tabular}

Sumber: Data primer yang diolah, 2018

\section{Uji Validitas.}

Menurut Ferdinand (2011), validity dimaksudkan sebagai “to measure what should be measure”. Bila ingin mengukur sesuatu, maka validitas berhubungan dengan mengukur alat yang digunakan yaitu apakah alat tersebut dapat mengukur hal yang akan diukur. Untuk menguji validitas digunakan uji Korelasi Product Moment dengan kriteria pengujian sebagai berikut jika nilai $r$ hitung $>\mathrm{r}$ tabel dan nilai signifikansi $<0,05$ maka dapat dikatakan bahwa indikator adalah valid. Jika nilai $\mathrm{r}$ hitung $<\mathrm{r}$ tabel dan nilai signifikansi $>0,05$ maka dapat dikatakan bahwa indikator tidak valid.

Tabel 2

Hasil Uji Validitas Indikator Variabel Penelitian

\begin{tabular}{|l|l|c|c|c|}
\hline Variabel Penelitian & Indikator & Koef Korelasi & Signifikansi & Keterangan \\
\hline \multirow{4}{*}{$\begin{array}{l}\text { Kesadaran Merek } \\
\text { Brand Awareness) }\end{array}$} & $\mathrm{X} 1 \_1$ & 0,795 & 0,000 & valid \\
\cline { 2 - 5 } & $\mathrm{X} 1 \_2$ & 0,763 & 0,000 & valid \\
\cline { 2 - 5 } & $\mathrm{X} 1 \_3$ & 0,482 & 0,000 & valid \\
\cline { 2 - 5 } & $\mathrm{X} 1 \_4$ & 0,738 & 0,000 & valid \\
\hline \multirow{4}{*}{$\begin{array}{l}\text { Asosiasi Merek } \\
\text { (Brand }\end{array}$} & $\mathrm{X} 2 \_1$ & 0,635 & 0,000 & valid \\
\cline { 2 - 5 } & $\mathrm{X} 2 \_2$ & 0,694 & 0,000 & valid \\
\cline { 2 - 5 } & $\mathrm{X} 2 \_3$ & 0,526 & 0,000 & valid \\
\cline { 2 - 5 } & $\mathrm{X} 2 \_4$ & 0,662 & 0,000 & valid \\
\hline \multirow{3}{*}{$\begin{array}{l}\text { Kualitas Merek } \\
\text { (Perceived Quality) }\end{array}$} & $\mathrm{X} 3 \_1$ & 0,786 & 0,000 & valid \\
\cline { 2 - 5 } & $\mathrm{X} 3 \_2$ & 0,595 & 0,000 & valid \\
\cline { 2 - 5 } & $\mathrm{X} 3 \_3$ & 0,801 & 0,000 & valid \\
\cline { 2 - 5 } & $\mathrm{X} 3 \_4$ & 0,799 & 0,000 & valid \\
\hline \multirow{2}{*}{$\begin{array}{l}\text { Loyalitas Merek } \\
\text { (Brand Loyalty) }\end{array}$} & $\mathrm{X} 4 \_1$ & 0,889 & 0,000 & valid \\
\cline { 2 - 5 } & $\mathrm{X} 4 \_2$ & 0,875 & 0,000 & valid \\
\cline { 2 - 5 } & $\mathrm{X} 4 \_3$ & 0,865 & 0,000 & valid \\
\hline
\end{tabular}




\section{Alat Analisis Data}

Analisis indeks jawaban responden digunakan untuk mengetahui persepsi umum responden mengenai variabel-variabel yang diteliti, serta mendapatkan gambaran mengenai derajat persepsi responden pada tiap variabel yang diteliti. Menggunakan alat analisis angka indeks dapat menentukan tinggi atau rendahnya nilai tiap variabel ekuitas merek dengan menggolongkan hasil nilai indeks ke rentang skala yang telah ditentukan. Mengutip dari buku yang ditulis oleh Ferdinand (2011), rumus untuk nilai indeks yaitu:

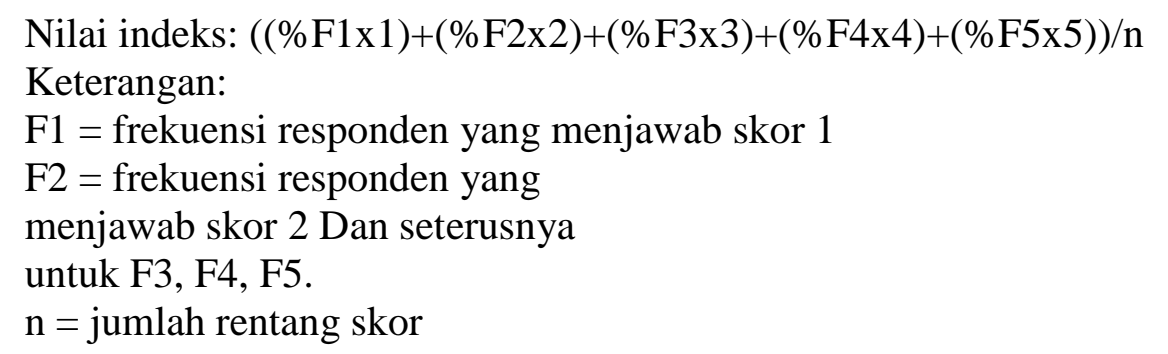
Dengan menggunakan kriteria tiga kotak (Three-box Method), maka rentang skala nya adalah: $40.01-40=$ Rendah

$$
\begin{aligned}
& 40.01-70=\text { Sedang } \\
& 70.01-100=\text { Tinggi }
\end{aligned}
$$

\section{Uji Komparatif}

Uji beda yang digunakan dalam penelitian ini adalah uji beda statistik non parametric, yaitu Mann Whitney (U-Test). Uji Mann-Whitney (U-Test) digunakan untuk menguji hipotesis komparatif dua sampel independen ketika distribusi data penelitian tidak memenuhi asumsi normalitas. Jika signifikansi $<0,05$ artinya terdapat perbedaan yang signifikan. Jika signifikansi $>0,05$ artinya tidak terdapat perbedaan yang signifikansi

\section{HASIL PENELITIAN DAN PEMBAHASAN}

Penelitian ini melakukan studi mengenai perbedaan ekuitas merek yang dilakukan pada merek kosmetik Etude House dan Wardah. Data mengenai ekuitas merek diperoleh melalui kuesioner yang diisi oleh mahasiswa pada kampus UNIKA Soegijapranata, Universitas Dian Nuswantoro, Universitas 
Diponegoro, dan Universitas Negeri Semarang yang dilakukan dua kali periode penelitian. Periode penelitian pertama dilakukan pada 22-26 Januari 2017 sedangkan periode kedua dilakukan pada 15-19 Februari 2017. Selama kedua periode tersebut diperoleh sebanyak 196 responden yang kemudian akan digunakan sebagai data dan sumber informasi yang diperlukan untuk studi ini.

\section{Deskripsi Karakteristik Responden}

Analisis ini dilakukan untuk memberikan gambaran mengenai karakteristik responden pengguna produk kosmetik di empat universitas yang berlokasi di Semarang, yaitu UNIKA Soegijapranata, Universitas Dian Nuswantoro, Universitas Diponegoro, dan Universitas Negeri Semarang. Berikut ini uraian deskripsi karakteristik responden berdasarkan jenis kosmetik yang diamati.

\section{Karakteristik Responden Pengguna Kosmetik Merek Etude House}

Dari 196 orang responden yang menjadi sampel dalam penelitian ini, diperoleh responden sebanyak 78 yang menggunakan produk kosmetik merek Etude House. Berikut ini disajikan hasil analisis karakteristik yang diperoleh dalam studi ini untuk responden yang menggunakan kosmetik merek Etude House.

Hasil analisis deskriptif terhadap jenis kelamin responden menunjukkan bahwa terdapat 75 orang $(97,4 \%)$ perempuan dan terdapat 3 orang $(3,8 \%)$ lakilaki yang menggunakan kosmetik Etude House. Hal ini menunjukkan bahwa yang menggunakan kosmetik Etude House sebagian besar adalah perempuan.Terdapat 68 orang $(87,2 \%)$ responden yang berasal dari UNIKA dan 10 orang $(12,8 \%)$ responden yang berasal dari UNDIP sedangkan mahasiswa dari UDINUS dan UNNES tidak ada yang menggunakan kosmetik merek Etude House. Temuan ini menunjukkan bahwa kosmetik merek Etude House menjadi preferensi kosmetik bagi mahasiswa UNIKA dan UNDIP. 


\section{Karakteristik Responden Pengguna Kosmetik Merek Wardah}

Dari 196 orang responden yang menjadi sampel dalam penelitian ini, diperoleh responden sebanyak 118 yang menggunakan produk kosmetik merek Wardah. Berikut ini disajikan hasil analisis karakteristik yang diperoleh dalam studi ini untuk responden yang menggunakan kosmetik merek Wardah.

Hasil analisis deskriptif terhadap jenis kelamin responden menunjukkan bahwa terdapat 116 orang (98,3\%) perempuan dan terdapat 2 orang $(1,7 \%)$ lakilaki yang menggunakan kosmetik merek Wardah. Hal ini menunjukkan bahwa yang menggunakan kosmetik Wardah sebagian besar adalah perempuan.

Terdapat 44 orang $(37,3 \%)$ responden yang berasal dari UNIKA dan 39 orang $(33,1 \%)$ responden yang berasal dari UNNES yang menggunakan kosmetik merek Wardah. Temuan ini menunjukkan bahwa kosmetik merek Wardah menjadi preferensi kosmetik bagi mahasiswa UNIKA dan UNNES.

\section{Deskripsi Jawaban Responden Kosmetik Merek Etude House}

\section{Deskripsi Jawaban Variabel Kesadaran Merek (Brand Awareness) Kosmetik Etude House}

Berikut ini deskripsi jawaban responden pada indikator-indikator variabel kesadaran merek (brand awareness) untuk kosmetik merek Etude House yang diukur dengan menggunakan empat indikator yang meliputi mengingat produk kosmetik merek Etude House, mengetahui produk kosmetik merek Etude House, produk kosmetik merek Etude House akan muncul di benak konsumen saat konsumen mengingat produk kosmetik kosmetik, dan menyadari produk kosmetik merek Etude House. 
Tabel 3

Indeks Variabel Kesadaran Merek (Brand Awareness) Kosmetik Etude House

\begin{tabular}{|c|c|c|c|c|c|c|c|c|c|c|c|}
\hline \multirow[t]{3}{*}{ Indikator } & \multicolumn{10}{|c|}{$\begin{array}{c}\text { Frekuensi Jawaban Responden Tentang } \\
\text { Kesadaran Merek (Brand Awareness) Berdasarkan Skala Nilai } \\
\text { Jawaban }\end{array}$} & \multirow[t]{3}{*}{ Indeks } \\
\hline & \multicolumn{2}{|c|}{1} & \multicolumn{2}{|c|}{2} & \multicolumn{2}{|c|}{3} & \multicolumn{2}{|c|}{4} & \multicolumn{2}{|c|}{5} & \\
\hline & Frek & $\%$ & Frek & $\%$ & Frek & $\%$ & Frek & $\%$ & Frek & $\%$ & \\
\hline $\begin{array}{l}\text { Mengingat } \\
\text { merek }\end{array}$ & 0 & 0,0 & 7 & 9,0 & 19 & 24,4 & 39 & 50,0 & 13 & 16,7 & 74,9 \\
\hline $\begin{array}{l}\text { Mengetahui } \\
\text { merek }\end{array}$ & 2 & 2,6 & 3 & 3,8 & 21 & 26,9 & 29 & 37,2 & 23 & 29,5 & 77,4 \\
\hline $\begin{array}{l}\text { Muncul di } \\
\text { benak } \\
\text { konsumen }\end{array}$ & 0 & 0,0 & 1 & 1,3 & 4 & 5,1 & 20 & 25,6 & 53 & 67,9 & 92,0 \\
\hline $\begin{array}{l}\text { Menyadari } \\
\text { merek }\end{array}$ & 0 & 0,0 & 3 & 3,8 & 6 & 7,7 & 42 & 53,8 & 27 & 34,6 & 83,8 \\
\hline \multicolumn{11}{|c|}{ Rata-Rata } & 82,0 \\
\hline
\end{tabular}

Sumber: Data primer yang diolah, 2018

Hasil perhitungan nilai indeks menunjukkan bahwa nilai rata-rata indeks untuk variabel kesadaran merek (brand awareness) kosmetik merek Etude House adalah sebesar 82,0. Hal ini menunjukkan bahwa kesadaran merek (brand awareness) terhadap merek kosmetik Etude House termasuk dalam kategori tinggi. Dari keempat indikator yang digunakan untuk mengukur variabel kesadaran merek (brand awareness) dapat diketahui bahwa indikator mengenai pengetahuan merek merupakan indikator dengan indeks terendah sedangkan indikator mengenai muncul di benak konsumen merupakan indikator dengan indeks tertinggi. 
Tabel 4

Temuan Variabel Kesadaran Merek (Brand Awareness) Kosmetik Etude House

\begin{tabular}{|c|c|c|}
\hline Variabel & Indeks & Temuan Merek \\
\hline $\begin{array}{l}\text { Kesadaran Merek } \\
\text { (brand awareness) }\end{array}$ & $\begin{array}{l}82,0 \\
\text { (tinggi) }\end{array}$ & $\begin{array}{ll}\text { - } & \text { Maybeline = } 15(19,2 \%) \\
\text { - } & \text { Etude House = } 13(16,6 \%) \\
\text { - } & \text { Make Over = } 10(12,8 \%) \\
\text { - } & \text { Wardah = } 8(10,2 \%) \\
\text { - } & \text { NYX =4 }(5,1 \%) \\
\text { - } & \text { The Face Shop =4 (5,1\%) } \\
\text { - } & \text { Nature Republic = 3 }(3,8 \%) \\
\text { - } & \text { Oriflame = } 2(2,5 \%) \\
\text { - } & \text { L'oreal = } 2(2,5 \%) \\
\text { - } & \text { Ultima = } 2(2,5 \%) \\
\text { - } & \text { MAC = } 2(2,5 \%) \\
\text { - } & \text { Cetaphil = } 1(1,2 \%) \\
\text { - } & \text { Sephora = } 1(1,2 \%) \\
\text { - } & \text { Borjouis = } 1(1,2 \%) \\
\text { - } & \text { Too Faced = } 1(1,2 \%) \\
\text { - } & \text { Natural Pacific }=1(1,2 \%) \\
\text { - } & \text { Make Up Forever = } 1(1,2 \%) \\
\text { - } & \text { Dior = } 1(1,2 \%) \\
\text { - } & \text { Purbasari = } 1(1,2 \%) \\
\text { - } & \text { Kryolan = } 1(1,2 \%) \\
\text { - } & \text { Anastasia Beverly Hills = } 1(1,2 \%) \\
\text { - } & \text { Jefree Stars = } 1(1,2 \%) \\
\text { - } & \text { Zoeva = } 1(1,2 \%) \\
\text { - } & \text { Benefit = } 1(1,2 \%)\end{array}$ \\
\hline
\end{tabular}

Sumber: Data primer yang diolah, 2018

Pada pertanyaan terbuka variabel kesadaran merek, responden diminta untuk menyebutkan tiga merek kosmetik yang muncul di benak responden ketika mengingat produk kosmetik. Namun, tidak semua menyebut tiga merek. Berdasarkan hasil rekapitulasi pertanyaan terbuka yang dikaji secara kualitatif, dapat diketahui bahwa responden sebanyak 15 orang responden $(19,2 \%)$ menyebutkan produk kosmetik merek Maybelline. Produk kosmetik yang banyak disebutkan kedua yaitu merek Etude House, sebanyak 13 orang responden (16,6\%) yang menyebutkan. Selain itu, mereka juga masih dapat menyebutkan merek-merek yang lain. Hal ini menunjukkan bahwa responden melek merek atau sadar dengan berbagai jenis merek kosmetik. 


\section{Deskripsi Jawaban Variabel Asosiasi Merek (Brand Association) Kosmetik Etude House}

Berikut ini deskripsi jawaban responden pada indikator-indikator variabel asosiasi merek (brand association) kosmetik Etude House yang diukur dengan menggunakan empat indikator yang meliputi harga produk kosmetik merek Etude House terjangkau, bahan-bahan yang digunakan aman dan bebas dari bahan kimia, kemasan menarik, dan kemudahan konsumen dalam mendapat produk kosmetik merek Etude House.

Tabel 5

Indeks Variabel Asosiasi Merek (Brand Association) Kosmetik Etude House

\begin{tabular}{|c|c|c|c|c|c|c|c|c|c|c|c|}
\hline \multirow{3}{*}{ Indikator } & \multicolumn{10}{|c|}{$\begin{array}{c}\text { Frekuensi Jawaban Responden Tentang } \\
\text { Asosiasi Merek (Brand Association) Berdasarkan Skala Nilai Jawaban }\end{array}$} & \multirow{3}{*}{ Indeks } \\
\hline & \multicolumn{2}{|c|}{1} & \multicolumn{2}{|c|}{2} & \multicolumn{2}{|c|}{3} & \multicolumn{2}{|c|}{4} & \multicolumn{2}{|c|}{5} & \\
\hline & Frek & $\%$ & Frek & $\%$ & Frek & $\%$ & Frek & $\%$ & Frek & $\%$ & \\
\hline $\begin{array}{l}\text { Harga } \\
\text { terjangkau }\end{array}$ & 2 & 2,6 & 10 & 12,8 & 43 & 55,1 & 20 & 25,6 & 3 & 3,8 & 63,0 \\
\hline $\begin{array}{l}\text { Bahan } \\
\text { kosmetik } \\
\text { aman }\end{array}$ & 0 & 0,0 & 0 & 0,0 & 24 & 30,8 & 38 & 48,7 & 16 & 20,5 & 77,9 \\
\hline $\begin{array}{l}\text { Kemasan } \\
\text { menarik }\end{array}$ & 0 & 0,0 & 0 & 0,0 & 3 & 3,8 & 37 & 47,4 & 38 & 48,7 & 88,9 \\
\hline $\begin{array}{l}\text { Mudah } \\
\text { didapat }\end{array}$ & 0 & 0,0 & 1 & 1,3 & 13 & 16,7 & 43 & 55,1 & 21 & 26,9 & 81,5 \\
\hline \multicolumn{11}{|c|}{ Rata-Rata } & 77,8 \\
\hline
\end{tabular}

Sumber: Data primer yang diolah, 2018

Hasil perhitungan nilai indeks menunjukkan bahwa nilai rata-rata indeks untuk variabel asosiasi merek (brand association) kosmetik Etude House adalah sebesar 77,8. Hal ini menunjukkan bahwa asosiasi merek (brand association) terhadap merek kosmetik Etude House termasuk dalam kategori tinggi. Dari keempat indikator yang digunakan untuk mengukur asosiasi merek (brand association), harga terjangkau merupakan indikator dengan indeks terendah sedangkan kemasan menarik merupakan indikator dengan indeks tertinggi. 


\section{Tabel 6}

Temuan Variabel Asosiasi Merek (Brand Association) Kosmetik Etude House

\begin{tabular}{|c|c|l|}
\hline Variabel & Indeks & \multicolumn{1}{c|}{ Temuan } \\
\hline & & - Hasil setelah digunakan terlihat bagus \\
& & - Terasa ringan di wajah \\
Asosiasi & & - Terlihat natural \\
Merek & 77,8 & - Simple dan mudah dibawa \\
(Brand & (tinggi) & - Kemasan praktis dan lucu \\
Association) & & - Mudah didapat karena di online shop ada \\
& & - Susah didapat karena konter hanya ada di \\
& & satu mall, sehingga harus di online. \\
\hline
\end{tabular}

Sumber: Data primer yang diolah, 2018

Berdasarkan hasil analisis kualitatif yang dilakukan pada pertanyaan terbuka dapat diketahui bahwa responden mengasosiasikan merek kosmetik yang dipakai dengan hasil yang didapat saat diaplikasikan. Temuan yang dapat dikaji dari hasil rekapan pertanyaan terbuka tentang pendapat responden untuk produk kosmetik merek Etude House adalah bahwa ketika diaplikasikan ke wajah, para responden berpendapat produk kosmetik terlihat bagus, terasa ringan dan juga terlihat natural. Dari segi kemasan, banyak responden berpendapat bahwa kemasan terasa praktis dan juga mudah dibawa. Produk yang memiliki gerai yang tersebar luas, ketersediaan produk pada layanan penjualan online menjadi pertimbangan-pertimbangan yang banyak dikemukakan oleh responden.

\section{Deskripsi Jawaban Variabel Persepsi Kualitas (Perceived Quality) Kosmetik Etude House}

Berikut ini deskripsi jawaban responden pada indikator-indikator variabel persepsi kualitas (perceived quality) kosmetik Etude House yang diukur dengan menggunakan empat indikator yang meliputi hasil pemakaian produk kosmetik merek Etude House terasa baik di kulit wajah konsumen, produk kosmetik merek Etude House memiliki banyak variasi jenis produk kosmetik yang lengkap, manfaat produk kosmetik merek Etude House yang 
dirasakan konsumen sesuai dengan klaim produk, dan produk kosmetik merek Etude House memiliki kualitas yang baik.

Tabel 7

Indeks Variabel Persepsi Kualitas (Perceived Quality) Kosmetik Etude House

\begin{tabular}{|c|c|c|c|c|c|c|c|c|c|c|c|}
\hline \multirow[t]{3}{*}{ Indikator } & \multicolumn{10}{|c|}{$\begin{array}{c}\text { Frekuensi Jawaban Responden Tentang } \\
\text { Persepsi Kualitas (Perceived Quality) Berdasarkan Skala Nilai } \\
\text { Jawaban }\end{array}$} & \multirow[t]{3}{*}{ Indeks } \\
\hline & \multicolumn{2}{|c|}{1} & \multicolumn{2}{|c|}{2} & \multicolumn{2}{|c|}{3} & \multicolumn{2}{|c|}{4} & \multicolumn{2}{|c|}{5} & \\
\hline & Frek & $\%$ & Frek & $\%$ & Frek & $\%$ & Frek & $\%$ & Frek & $\%$ & \\
\hline $\begin{array}{l}\text { Hasil } \\
\text { penggunaan } \\
\text { bagus }\end{array}$ & 0 & 0,0 & 0 & 0,0 & 15 & 19,2 & 42 & 53,8 & 21 & 26,9 & 81,5 \\
\hline $\begin{array}{l}\text { Variasi } \\
\text { jenis } \\
\text { produk }\end{array}$ & 0 & 0,0 & 0 & 0,0 & 9 & 11,5 & 34 & 43,6 & 35 & 44,9 & 86,7 \\
\hline $\begin{array}{l}\text { Klaim } \\
\text { produk } \\
\text { terpenuhi }\end{array}$ & 0 & 0,0 & 0 & 0,0 & 19 & 24,4 & 51 & 65,4 & 8 & 10,3 & 77,3 \\
\hline $\begin{array}{l}\text { Kualitas } \\
\text { keseluruhan } \\
\text { baik }\end{array}$ & 0 & 0,0 & 5 & 6,4 & 27 & 34,6 & 34 & 43,6 & 12 & 15,4 & 73,6 \\
\hline & & & & Rato & Rata & & & & & & 79,7 \\
\hline
\end{tabular}

Sumber: Data primer yang diolah, 2018

Hasil perhitungan nilai indeks menunjukkan bahwa nilai rata-rata indeks untuk variabel persepsi kualitas (perceived quality) kosmetik Etude House adalah sebesar 79,8. Hal ini menunjukkan bahwa persepsi kualitas (perceived quality) terhadap merek kosmetik Etude House termasuk dalam kategori tinggi. Berdasarkan hasil perhitungan indeks juga dapat diketahui bahwa kualitas baik merupakan indikator dengan indeks terendah sedangkan variasi jenis produk merupakan indikator dengan indeks tertinggi. 
Tabel 8

Temuan Variabel Persepsi Kualitas (Perceived Quality) Kosmetik Etude House

\begin{tabular}{|c|c|c|}
\hline Variabel & Indeks & Temuan \\
\hline $\begin{array}{l}\text { Persepsi Kualitas } \\
\text { (Perceived Quality) }\end{array}$ & $\begin{array}{c}79,8 \\
\text { (tinggi) }\end{array}$ & $\begin{array}{l}\text { - } \text { Bagus dan natural hasilnya } \\
\text { - Merasa cocok dan ringan dipakai } \\
\text { - } \quad \text { Tidak menimbulkan jerawat } \\
\text { - Merasa biasa saja dengan produk } \\
\text { karena hanya sekedar menggunakan } \\
\text { produk (tidak merasa manfaat) } \\
\text { - Efek negatif jangka panjang tidak ada } \\
\text { - } \quad \text { Produk kosmetik mampu menutupi } \\
\text { warna wajah dengan rata } \\
\text { - Variasi warna untuk BB Cream atau } \\
\text { foundation banyak yang terlalu muda } \\
\text { karena menyesuaikan kulit orang } \\
\text { Korea } \\
\text { - Variasi warna untuk liptint cukup } \\
\text { banyak } \\
\text { - Pelayanan di toko Etude House cukup } \\
\text { ramah. }\end{array}$ \\
\hline
\end{tabular}

Sumber: Data primer yang diolah, 2018

Kajian pertanyaan terbuka untuk variabel persepsi kualitas dapat diketahui bahwa responden sangat detail dalam memperhatikan kualitas kosmetik yang dipakainya. Kesan kualitas yang dipertimbangkan konsumen meliputi kosmetik yang mudah menempel, tidak berat, memberikan kesan natural, mampu menutup dengan merata, tidak menimbulkan jerawat, tidak berefek negatif dalam jangka panjang. Selain itu, konsumen yang menjadi responden juga mengatakan bahwa variasi warna untuk beberapa produk cukup baik terutama produk liptint. Banyak responden yang menyukai produk liptint dari Etude House. Sedangkan produk BB Cream atau foundation masih dirasa terlalu terang untuk kulit orang Indonesia. Di samping itu, pelayanan di toko juga baik.

\section{Deskripsi Jawaban Variabel Loyalitas Merek (Brand Loyalty) Kosmetik}

\section{Etude House}

Berikut ini deskripsi jawaban responden pada indikator-indikator variabel loyalitas merek (brand loyalty) kosmetik Etude House yang diukur dengan 
menggunakan tiga indikator yang meliputi membeli produk kosmetik merek Etude House kembali, konsumen merasa puas dengan produk kosmetik merek Etude House, dan merekomendasikan produk kosmetik merek Etude House ke orang lain.

Tabel 9

Indeks Variabel Loyalitas Merek (Brand Loyalty) Kosmetik Etude House

\begin{tabular}{|c|c|c|c|c|c|c|c|c|c|c|c|}
\hline \multirow[t]{3}{*}{ Indikator } & \multicolumn{10}{|c|}{$\begin{array}{c}\text { Frekuensi Jawaban Responden Tentang } \\
\text { Loyalitas Merek (Brand Loyalty) Berdasarkan Skala Nilai } \\
\text { Jawaban }\end{array}$} & \multirow[t]{3}{*}{ Indeks } \\
\hline & \multicolumn{2}{|c|}{1} & \multicolumn{2}{|c|}{2} & \multicolumn{2}{|c|}{3} & \multicolumn{2}{|r|}{4} & \multicolumn{2}{|c|}{5} & \\
\hline & Frek & $\%$ & Frek & $\%$ & Frek & $\%$ & Frek & $\%$ & Frek & $\%$ & \\
\hline Membeli kembali & 0 & 0,0 & 0 & 0,0 & 14 & 17,9 & 42 & 53,8 & 22 & 28,2 & 82,0 \\
\hline Merasa puas & 0 & 0,0 & 0 & 0,0 & 12 & 15,4 & 48 & 61,5 & 18 & 23,1 & 81,5 \\
\hline $\begin{array}{l}\text { Merekomendasikan } \\
\text { produk }\end{array}$ & 0 & 0,0 & 0 & 0,0 & 18 & 23,1 & 41 & 52,6 & 19 & 24,4 & 80,3 \\
\hline \multicolumn{11}{|c|}{ Rata-Rata } & 81,3 \\
\hline
\end{tabular}

Sumber: Data primer yang diolah, 2018

Hasil perhitungan nilai indeks menunjukkan bahwa nilai rata-rata indeks untuk variabel loyalitas merek (brand loyalty) kosmetik Etude House adalah sebesar 81,3. Hal ini menunjukkan bahwa loyalitas merek (brand loyalty) terhadap merek kosmetik Etude House termasuk dalam kategori tinggi. Hasil perhitungan nilai indeks untuk masing-asing indikator dapat diketahui bahwa merekomendasikan produk merupakan indikator dengan indeks terendah sedangkan membeli kembali merupakan indikator dengan indeks tertinggi.

Tabel 10

Temuan Variabel Loyalitas Merek (Brand Loyalty) Kosmetik Etude House

\begin{tabular}{|c|c|l|}
\hline Variabel & Indeks & \multicolumn{1}{c|}{ Temuan } \\
\hline & & - Harga terjangkau $=19$ \\
& & - Terbiasa dengan produknya $=26$ \\
& & - Suka dengan mereknya $=12$ \\
Loyalitas Merek & 81,3 & - Puas dengan kualitasnya $=22$ \\
(Brand Loyalty) & (tinggi) & Alasan lain: \\
& & - Warna bagus $=2$ \\
& & - Review tentang produk bagus $=1$ \\
\hline
\end{tabular}

Sumber: Data primer yang diolah, 2018 
Di bagian variabel loyalitas merek, responden diminta untuk menjawab apa alasan menggunakan produk kosmetik merek Etude House. Responden dapat memilih pilihan yang telah tersedia dan juga memberikan alasan lain. Pilihan yang tersedia adalah harga produk terjangkau, sudah terbiasa menggunakan produk merek tersebut, puas dengan kualitas merek, hanya sekedar suka dengan merek. Dari 82 jawaban responden, didapat jawaban paling dominan yaitu terbiasa dengan produk kosmetik merek Etude House.

\section{Deskripsi Jawaban Responden Kosmetik Merek Wardah}

\section{Deskripsi Jawaban Variabel Kesadaran Merek (Brand Awareness) Kosmetik Wardah}

Berikut ini deskripsi jawaban responden pada indikator-indikator variabel kesadaran merek (brand awareness) untuk kosmetik merek Wardah yang diukur dengan menggunakan empat indikator yang meliputi mengingat produk kosmetik merek Wardah, mengetahui produk kosmetik merek Wardah, produk kosmetik merek Wardah akan muncul di benak konsumen ketika konsumen membutuhkan produk kosmetik, dan menyadari produk kosmetik merek Wardah.

\section{Tabel 11}

\section{Indeks Variabel Kesadaran Merek (Brand Awareness) Kosmetik Wardah}

\begin{tabular}{|c|c|c|c|c|c|c|c|c|c|c|c|}
\hline \multirow[t]{3}{*}{ Indikator } & \multicolumn{10}{|c|}{$\begin{array}{c}\text { Frekuensi Jawaban Responden Tentang } \\
\text { Kesadaran Merek (Brand Awareness) Berdasarkan Skala Nilai } \\
\text { Jawaban } \\
\end{array}$} & \multirow[t]{3}{*}{ Indeks } \\
\hline & \multicolumn{2}{|c|}{1} & \multicolumn{2}{|c|}{2} & \multicolumn{2}{|c|}{3} & \multicolumn{2}{|c|}{4} & \multicolumn{2}{|c|}{5} & \\
\hline & Frek & $\%$ & Frek & $\%$ & Frek & $\%$ & Frek & $\%$ & Frek & $\%$ & \\
\hline $\begin{array}{l}\text { Mengingat } \\
\text { merek }\end{array}$ & 2 & 1,7 & 18 & 15,3 & 44 & 37,3 & 42 & 35,6 & 12 & 10,2 & 67,5 \\
\hline $\begin{array}{l}\text { Mengetahui } \\
\text { merek }\end{array}$ & 0 & 0,0 & 5 & 4,2 & 37 & 31,4 & 59 & 50,0 & 17 & 14,4 & 74,9 \\
\hline $\begin{array}{l}\text { Muncul di } \\
\text { benak } \\
\text { konsumen }\end{array}$ & 0 & 0,0 & 2 & 1,7 & 6 & 5,1 & 33 & 28,0 & 77 & 65,3 & 91,4 \\
\hline $\begin{array}{l}\text { Menyadari } \\
\text { merek }\end{array}$ & 0 & 0,0 & 5 & 4,2 & 22 & 18,6 & 56 & 47,5 & 35 & 29,7 & 80,5 \\
\hline & & & & Rata & ata & & & & & & 78,6 \\
\hline
\end{tabular}

Sumber: Data primer yang diolah, 2018 
Hasil perhitungan nilai indeks menunjukkan bahwa nilai rata-rata indeks untuk variabel kesadaran merek (brand awareness) untuk kosmetik merek Wardah adalah sebesar 78,6. Hal ini menunjukkan bahwa kesadaran merek (brand awareness) terhadap merek kosmetik Wardah termasuk dalam kategori tinggi. Hasil perhitungan indeks juga memberikan informasi bahwa indikator mengingat merek merupakan indikator dengan indeks terendah sedangkan tertanam di benak konsumen sebagai indikator dengan indeks tertinggi.

Tabel 12

Temuan Variabel Kesadaran Merek (Brand Awareness) Kosmetik Wardah

\begin{tabular}{|c|c|c|}
\hline Variabel & Indeks & Temuan Merek \\
\hline $\begin{array}{l}\text { Kesadaran Merek } \\
\text { (Brand Awareness) }\end{array}$ & $\begin{array}{c}78,6 \\
\text { (tinggi) }\end{array}$ & 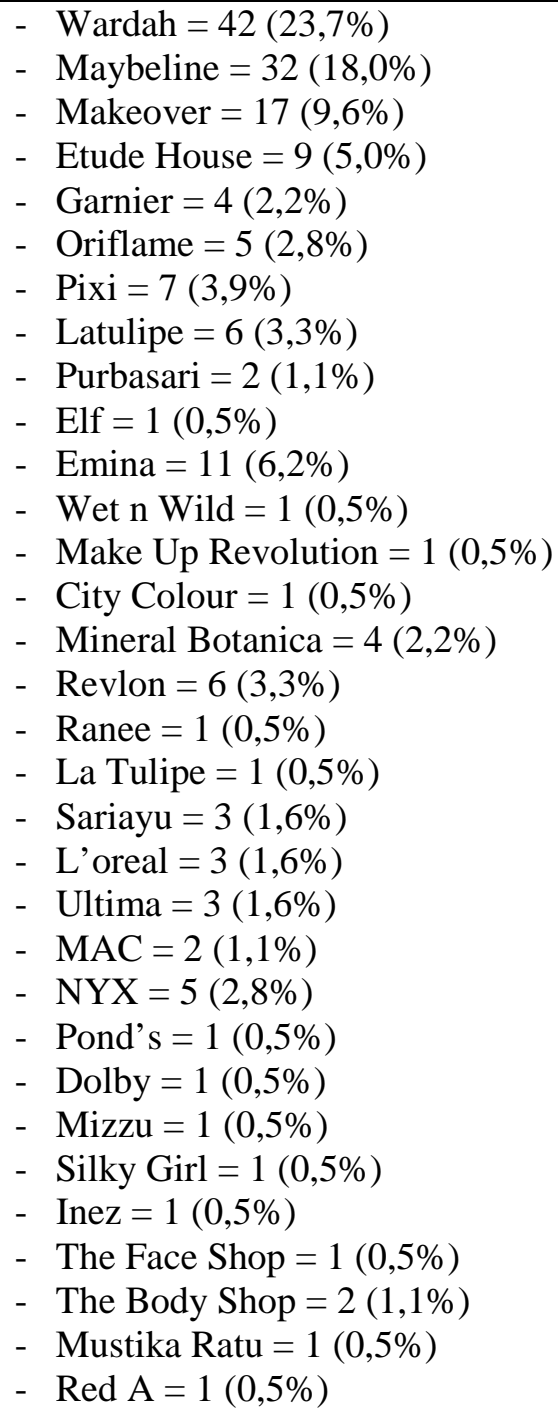 \\
\hline
\end{tabular}

Sumber: Data primer yang diolah, 2018 
Responden memiliki tingkat kesadaran merek yang tinggi. Hal ini dapat dilihat dari variasi jawaban terbuka pada variabel kesadaran merek. Responden sangat sadar akan kehadiran produk kosmetik merek Wardah. Hal ini dapat dilihat dari jumlah responden, yaitu sebanyak 42 orang (23,7\%) yang menyebutkan Wardah sebagai merek kosmetik. Selain itu, dari sekian jawaban yang disebutkan, Maybelline merupakan merek yang paling banyak disebutkan.

\section{Deskripsi Jawaban Variabel Asosiasi Merek (Brand Association) \\ Kosmetik Wardah}

Berikut ini deskripsi jawaban responden pada indikator-indikator variabel asosiasi merek (brand association) kosmetik Wardah yang diukur dengan menggunakan empat indikator yang meliputi harga produk kosmetik merek Wardah terjangkau, bahan-bahan yang digunakan aman dan bebas dari bahan kimia, kemasan menarik, dan kemudahan konsumen dalam mendapat produk kosmetik merek Wardah.

Tabel 13

Indeks Variabel Asosiasi Merek (Brand Association) Kosmetik Wardah

\begin{tabular}{|c|c|c|c|c|c|c|c|c|c|c|c|}
\hline \multirow{3}{*}{ Indikator } & \multicolumn{10}{|c|}{$\begin{array}{c}\text { Frekuensi Jawaban Responden Tentang } \\
\text { Asosiasi Merek (Brand Association) Berdasarkan Skala Nilai Jawaban }\end{array}$} & \multirow{3}{*}{ Indeks } \\
\hline & \multicolumn{2}{|c|}{1} & \multicolumn{2}{|c|}{2} & \multicolumn{2}{|c|}{3} & \multicolumn{2}{|c|}{4} & \multicolumn{2}{|c|}{5} & \\
\hline & Frek & $\%$ & Frek & $\%$ & Frek & $\%$ & Frek & $\%$ & Frek & $\%$ & \\
\hline $\begin{array}{l}\text { Harga } \\
\text { terjangkau }\end{array}$ & 0 & 0,0 & 5 & 4,2 & 24 & 20,3 & 57 & 48,3 & 32 & 27,1 & 79,6 \\
\hline $\begin{array}{l}\text { Bahan } \\
\text { kosmetik } \\
\text { aman }\end{array}$ & 0 & 0,0 & 0 & 0,0 & 31 & 26,3 & 64 & 54,2 & 23 & 19,5 & 78,6 \\
\hline $\begin{array}{l}\text { Kemasan } \\
\text { menarik }\end{array}$ & 0 & 0,0 & 7 & 5,9 & 34 & 28,8 & 60 & 50,8 & 17 & 14,4 & 74,7 \\
\hline $\begin{array}{l}\text { Mudah } \\
\text { didapat }\end{array}$ & 0 & 0,0 & 0 & 0,0 & 3 & 2,5 & 51 & 43,2 & 64 & 54,2 & 90,3 \\
\hline & & & & & & & & & & & 80,3 \\
\hline
\end{tabular}

Sumber: Data primer yang diolah, 2018

Hasil perhitungan nilai indeks menunjukkan bahwa nilai rata-rata indeks untuk variabel asosiasi merek (brand association) kosmetik Wardah adalah 
sebesar 80,8. Hal ini menunjukkan bahwa asosiasi merek (brand association) terhadap merek kosmetik wardah termasuk dalam kategori tinggi. Analisis deskriptif ini juga memberikan informasi bahwa kemasan menarik merupakan indikator yang dipersepsikan paling rendah oleh responden sedangkan mudah didapat merupakan indikator yang dipersepsikan paling tinggi oleh responden.

Tabel 14

Temuan Variabel Asosiasi Merek (Brand Association) Kosmetik Wardah

\begin{tabular}{|c|c|c|}
\hline Variabel & Indeks & Temuan \\
\hline $\begin{array}{c}\text { Asosiasi Merek } \\
\text { (Brand Association) }\end{array}$ & $\begin{array}{c}\text { 78,6 } \\
\text { (tinggi) }\end{array}$ & $\begin{array}{l}\text { - } \text { Mudah dan praktis dibawa } \\
\text { - } \text { Bedak dapat mengurangi minyak, } \\
\text { mencerahkan wajah. } \\
\text { - } \quad \text { Lipstick matte dapat menutupi } \\
\text { warna bibir } \\
\text { - Warna lipstick cocok dengan warna } \\
\text { kulit. } \\
\text { - } \text { Dapat menutupi noda atau bekas } \\
\text { jerawat di wajah } \\
\text { - Produk mudah sekali di dapat } \\
\text { contohnya di toko retail terdekat. }\end{array}$ \\
\hline
\end{tabular}

Sumber: Data primer yang diolah, 2018

Pemilihan kosmetik merek Wardah oleh konsumen tidak hanya berkaitan dengan mempercantik diri namun juga diasosiasikan dengan hal-hal lainnya. Kemudahan dibawa, kepraktisan penggunaan, ukuran kemasan yang pas, kemampuan lipstick yang dapat menutupi warna bibir, bedak yang dapat menutupi noda atau bekas jerawat di wajah dan tidak menimbulkan efek negatif ke wajah.

\section{Deskripsi Jawaban Variabel Persepsi Kualitas (Perceived Quality) Kosmetik Wardah}

Berikut ini deskripsi jawaban responden pada indikator-indikator variabel persepsi kualitas (perceived quality) kosmetik Wardah yang diukur dengan menggunakan empat indikator yang meliputi hasil pemakaian produk kosmetik merek Wardah terasa baik di kulit wajah konsumen, produk kosmetik merek Wardah memiliki banyak variasi jenis produk kosmetik yang lengkap, manfaat 
produk kosmetik merek Wardah yang dirasakan konsumen sesuai dengan klaim produk, dan produk kosmetik merek Wardah memiliki kualitas yang baik.

Tabel 15

Indeks Variabel Persepsi Kualitas (Perceived Quality) Kosmetik Wardah

\begin{tabular}{|c|c|c|c|c|c|c|c|c|c|c|c|}
\hline \multirow[t]{3}{*}{ Indikator } & \multicolumn{10}{|c|}{$\begin{array}{c}\text { Frekuensi Jawaban Responden Tentang } \\
\text { Persepsi Kualitas (Perceived Quality) Berdasarkan Skala Nilai } \\
\text { Jawaban }\end{array}$} & \multirow[t]{3}{*}{ Indeks } \\
\hline & \multicolumn{2}{|c|}{1} & \multicolumn{2}{|c|}{2} & \multicolumn{2}{|c|}{3} & \multicolumn{2}{|c|}{4} & \multicolumn{2}{|c|}{5} & \\
\hline & Frek & $\%$ & Frek & $\%$ & Frek & $\%$ & Frek & $\%$ & Frek & $\%$ & \\
\hline $\begin{array}{l}\text { Hasil } \\
\text { penggunaan } \\
\text { bagus }\end{array}$ & 0 & 0,0 & 3 & 2,5 & 29 & 24,6 & 64 & 54,2 & 22 & 18,6 & 77,7 \\
\hline $\begin{array}{l}\text { Variasi } \\
\text { jenis } \\
\text { produk }\end{array}$ & 0 & 0,0 & 1 & 0,8 & 9 & 7,6 & 67 & 56,8 & 41 & 34,7 & 85,0 \\
\hline $\begin{array}{l}\text { Klaim } \\
\text { produk } \\
\text { terpenuhi }\end{array}$ & 0 & 0,0 & 0 & 0,0 & 45 & 38,1 & 60 & 50,8 & 13 & 11,0 & 74,5 \\
\hline $\begin{array}{l}\text { Kualitas } \\
\text { baik }\end{array}$ & 0 & 0,0 & 13 & 11,0 & 53 & 44,9 & 41 & 34,7 & 11 & 9,3 & 68,4 \\
\hline \multicolumn{11}{|c|}{ Rata-Rata } & 76,5 \\
\hline
\end{tabular}

Sumber: Data primer yang diolah, 2018

Hasil perhitungan nilai indeks menunjukkan bahwa nilai rata-rata indeks untuk variabel persepsi kualitas (perceived quality) kosmetik Wardah adalah sebesar 76,4. Hal ini menunjukkan bahwa persepsi kualitas (perceived quality) terhadap merek kosmetik Wardah termasuk dalam kategori tinggi. Dari keempat indikator yang digunakan dalam pengukuran persepsi kualitas (perceived quality) dapat diketahui bahwa kualitas baik merupakan indikator dengan indeks terendah dan variasi jenis produk sebagai indikator dengan indeks tertinggi. 
Tabel 16

Temuan Variabel Persepsi Kualitas (Perceived Quality) Kosmetik Wardah

\begin{tabular}{|c|c|c|}
\hline Variabel & Indeks & Temuan \\
\hline $\begin{array}{l}\text { Persepsi Kualitas } \\
\text { (Perceived Quality) }\end{array}$ & $\begin{array}{c}76,4 \\
\text { (tinggi) }\end{array}$ & $\begin{array}{l}\text { - } \begin{array}{l}\text { Hasilnya memuaskan } \\
\text { - }\end{array} \text { Harga sesuai dengan kualitas } \\
\text { - } \quad \text { Cocok dan terbiasa } \\
\text { - } \quad \text { Tidak menimbulkan permasalahan } \\
\text { wajah atau efek samping (jerawat } \\
\text { atau kulit menjadi kering) } \\
\text { - } \quad \text { Lipstick tidak menyebabkan bibir } \\
\text { menjadi kering } \\
\text { - } \quad \text { Bedak dapat menahan minyak } \\
\text { wajah } \\
\text { - Tidak semua cocok, hanya beberapa } \\
\text { produk saja (misal eyeshadow atau } \\
\text { lipstick) } \\
\text { Terkadang produk } \\
\text { menimbulkan jerawat kecil } \\
\text { - Tekstur lipstick berat } \\
\text { - } \quad \text { Lipstick matte semakin lama } \\
\text { membuat bibir kering } \\
\text { - Variasi warna cukup banyak tiap } \\
\text { jenis produknya. } \\
\text { - Pelayanan di konter cukup ramah } \\
\text { namun ada yang kurang ramah. }\end{array}$ \\
\hline
\end{tabular}

Sumber: Data primer yang diolah, 2018

Responden saat ini telah cermat dan cerdas dalam memiliki produk terutama produk kosmetik. Hal ini dapat dilihat dari berbagai alasan yang ditemukan yang terkait dengan persepsi kualitas. Produk dengan hasil yang memuaskan, keterjangkauan harga sesuai dengan kualitas, kebiasaan dan cocok menggunakan, serta efek samping yang minimal. Selain itu responden juga berpendapat bahwa variasi warna per produk juga sudah cukup banyak dan hampir seluruh responden menyebutkan bahwa pelayanan di konter cukup ramah. Alasan-alasan yang dikemukakan tersebut terkait dengan persepsi kualitas yang melekat pada kosmetik merek Wardah. 


\section{Deskripsi Jawaban Variabel Loyalitas Merek (Brand Loyalty) Kosmetik Wardah}

Berikut ini deskripsi jawaban responden pada indikator-indikator variabel loyalitas merek (brand loyalty) kosmetik Wardah yang diukur dengan menggunakan tiga indikator yang meliputi membeli produk kosmetik merek Wardah kembali, konsumen merasa puas dengan produk kosmetik merek Wardah, dan merekomendasikan produk kosmetik merek Wardah ke orang lain.

Tabel 17

Indeks Variabel Loyalitas Merek (Brand Loyalty) Kosmetik Wardah

\begin{tabular}{|c|c|c|c|c|c|c|c|c|c|c|c|}
\hline \multirow[t]{3}{*}{ Indikator } & \multicolumn{10}{|c|}{$\begin{array}{c}\text { Frekuensi Jawaban Responden Tentang } \\
\text { Loyalitas Merek (Brand Loyalty) Berdasarkan Skala Nilai } \\
\text { Jawaban }\end{array}$} & \multirow[t]{3}{*}{ Indeks } \\
\hline & \multicolumn{2}{|c|}{1} & \multicolumn{2}{|c|}{2} & \multicolumn{2}{|c|}{3} & \multicolumn{2}{|c|}{4} & \multicolumn{2}{|c|}{5} & \\
\hline & Frek & $\%$ & Frek & $\%$ & Frek & $\%$ & Frek & $\%$ & Frek & $\%$ & \\
\hline $\begin{array}{l}\text { Membeli } \\
\text { kembali }\end{array}$ & 0 & 0,0 & 3 & 2,5 & 22 & 18,6 & 62 & 52,5 & 31 & 26,3 & 80,5 \\
\hline Merasa puas & 0 & 0,0 & 5 & 4,2 & 19 & 16,1 & 75 & 63,6 & 19 & 16,1 & 78,3 \\
\hline $\begin{array}{l}\text { Merekomendasi } \\
\text { kan produk }\end{array}$ & 0 & 0,0 & 4 & 3,4 & 35 & 29,7 & 60 & 50,8 & 19 & 16,1 & 75,9 \\
\hline \multicolumn{11}{|c|}{ Rata-Rata } & 78,2 \\
\hline
\end{tabular}

Sumber: Data primer yang diolah, 2018

Hasil perhitungan nilai indeks menunjukkan bahwa nilai rata-rata indeks untuk variabel loyalitas merek (brand loyalty) kosmetik Wardah adalah sebesar 78,2. Hal ini menunjukkan bahwa loyalitas merek (brand loyalty) terhadap merek kosmetik Wardah termasuk dalam kategori tinggi. Dari ketiga indikator yang digunakan untuk mengukur loyalitas merek dapat diketahui bahwa merekomendasikan produkmerupakan indikator dengan indeks terendah sedangkan indeks tertinggi diperoleh pada indikator tentang membeli kembali. 
Tabel 18

Temuan Variabel Loyalitas Merek (Brand Loyalty) Kosmetik Wardah

\begin{tabular}{|c|c|c|}
\hline Variabel & Indeks & Temuan \\
\hline $\begin{array}{l}\text { Loyalitas Merek } \\
\text { (Brand Loyalty) }\end{array}$ & $\begin{array}{c}78,2 \\
\text { (tinggi) }\end{array}$ & 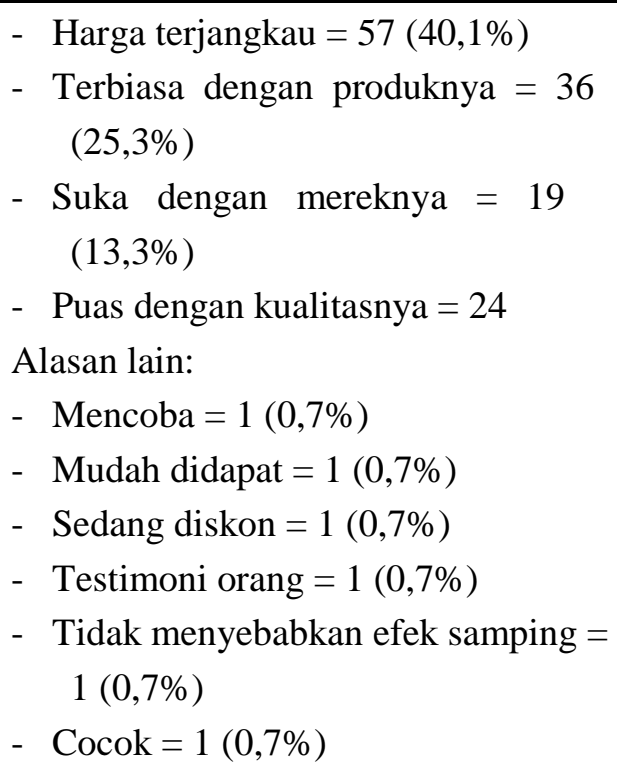 \\
\hline
\end{tabular}

Sumber: Data primer yang diolah, 2018

Di bagian variabel loyalitas merek, responden diminta untuk menjawab apa alasan menggunakan produk kosmetik merek Wardah. Responden dapat memilih pilihan yang telah tersedia dan juga memberikan alasan lain. Pilihan yang tersedia adalah harga produk terjangkau, sudah terbiasa menggunakan produk merek tersebut, puas dengan kualitas merek, hanya sekedar suka dengan merek. Jawaban dengan jawaban paling dominan yaitu harga terjangkau.

\section{Deskripsi Ekuitas Merek pada Kosmetik Merek Etude House dan Wardah}

Berikut ini deskripsi indeks persepsi responden atas ekuitas merek pada masing-masing kosmetik merek Etude House dan Wardah. 
Tabel 19

Indeks Ekuitas Merek Kosmetik Merek Etude House dan Wardah

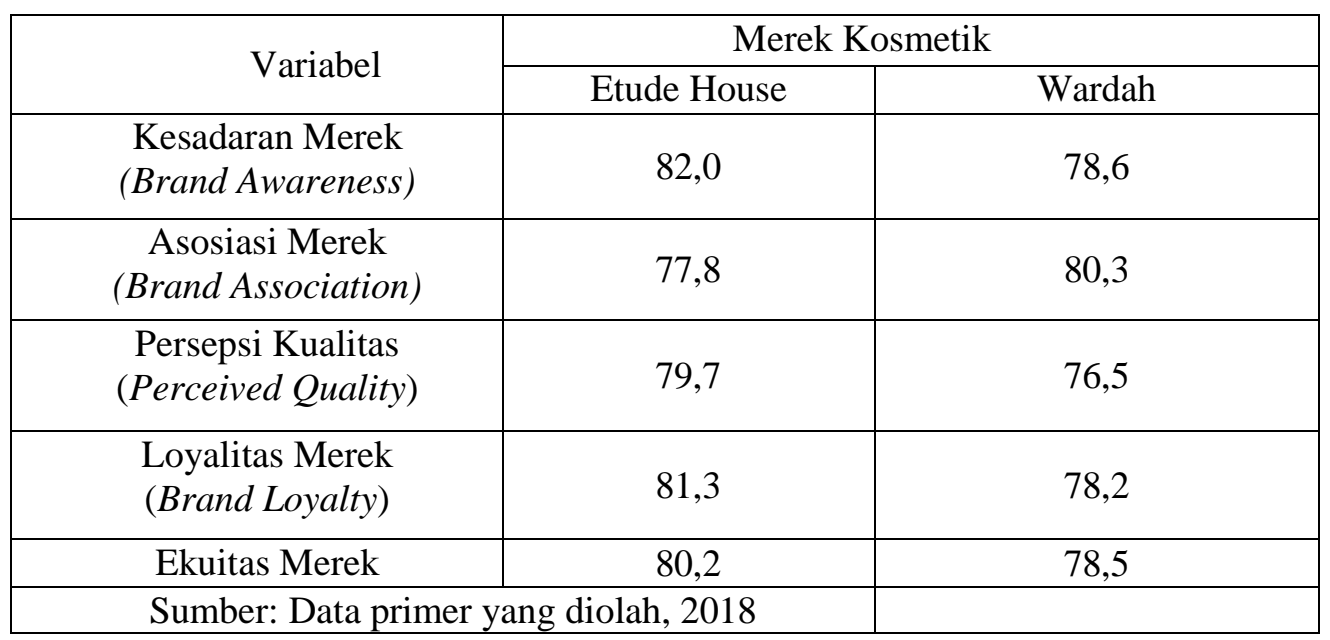

Berdasarkan hasil rekapitulasi perhitungan nilai indeks masing-masing variabel dapat diketahui bahwa rerata indeks untuk ekuitas merek kosmetik Etude adalah sebesar 80,2 sedangkan Wardah 78,5.

\section{Pengujian Perbedaan (Komparatif)}

\section{Uji Komparatif Kesadaran Merek (Brand Awareness)}

Bagian ini akan melakukan pengujian perbedaan kesadaran merek pada kosmetik merek wardah dan Etude House. Pengujian ada atau tidaknya perbedaan kesadaran merek (brand awareness) berdasarkan jenis merek kosmetik dilakukan dengan menganalisis nilai signifikansi dengan kriteria sebagai berikut: Jika signifikansi $<0,05$ artinya terdapat perbedaan yang signifikan. Jika signifikansi > 0,05 artinya tidak terdapat perbedaan yang signifikan. Hasil pengujian komparatif dengan Uji Mann Whitney menghasilkan nilai signifikansi sebesar 0,031 dimana nilai signifikansi tersebut lebih kecil dari 0,05, maka H1 diterima dan H0 ditolak. Artinya, kesadaran merek (brand awareness) kosmetik wardah berbeda dengan kesadaran merek (brand awareness) pada merek Etude House. 


\section{Uji Komparatif Asosiasi Merek (Brand Association)}

Bagian ini akan melakukan pengujian perbedaan asosiasi merek pada kosmetik merek wardah dan Etude House. Pengujian ada atau tidaknya perbedaan asosiasi merek (brand association) berdasarkan jenis merek kosmetik dilakukan dengan uji komparatif Mann Whitney menghasilkan nilai signifikansi sebesar 0,013 dimana nilai signifikansi tersebut lebih kecil dari 0,05, maka H1 diterima dan H0 ditolak. Artinya, asosiasi merek (brand association) kosmetik wardah berbeda dengan asosiasi merek (brand association) pada merek Etude House.

\section{Uji Komparatif Persepsi Kualitas (Perceived Quality)}

Bagian ini akan melakukan pengujian perbedaan persepsi kualitas pada kosmetik merek wardah dan Etude House. Pengujian ada atau tidaknya perbedaan persepsi kualitas (perceived quality) berdasarkan jenis merek kosmetik dilakukan dengan uji komparatif Mann Whitney menghasilkan nilai signifikansi sebesar 0,041 dimana nilai signifikansi tersebut lebih kecil dari 0,05, maka H1 diterima dan H0 ditolak. Artinya, persepsi kualitas (perceived quality) kosmetik wardah berbeda dengan persepsi kualitas (perceived quality) pada merek Etude House.

\section{Uji Komparatif Loyalitas Merek (Brand Loyalty)}

Bagian ini akan melakukan pengujian perbedaan loyalitas merek (brand loyalty) pada kosmetik merek wardah dan Etude House. Pengujian ada atau tidaknya perbedaan loyalitas merek (brand loyalty) berdasarkan jenis merek kosmetik dilakukan uji komparatif Mann Whitney yang menghasilkan nilai signifikansi sebesar 0,187 dimana nilai signifikansi tersebut lebih besar dari 0,05, maka H1 ditolak dan H0 diterima. Artinya, loyalitas merek (brand loyalty) kosmetik wardah tidak berbeda dengan loyalitas merek (brand loyalty) pada merek Etude House. 


\section{KESIMPULAN}

Hasil uji komparatif kesadaran merek (brand awareness) membuktikan bahwa H1 diterima dan H0 ditolak yang berarti kesadaran merek (brand awareness) kosmetik wardah berbeda dengan kesadaran merek (brand awareness) pada merek Etude House House. Hal ini disebabkan karena konsumen lebih mengingat dan mengenal Wardah daripada Etude House House. Wardah memiliki banyak konter kosmetik di hampir seluruh pusat perbelanjaan di berbagai kota. Namun, Etude House House hanya memiliki konter toko kosmetik nya di kota-kota tertentu saja.

Hasil uji komparatif asosiasi merek (brand assosiacion) membuktikan bahwa H1 diterima dan H0 ditolak. Artinya, asosiasi merek (brand association) kosmetik wardah berbeda dengan asosiasi merek (brand association) pada merek Etude House House. Perbedaan ini disebabkan karena perbedaan secara visual dari kemasan, Etude House House memiliki kemasan yang lebih menarik dan lucu. Kemudahan untuk menemukan produk pun juga mempengaruhi. Produk kosmetik Wardah lebih mudah ditemukan daripada produk kosmetik Etude House House.

Hasil uji komparatif persepsi kualitas (perceived quality) membuktikan bahwa H1 diterima dan H0 ditolak. Artinya, persepsi kualitas (perceived quality) kosmetik wardah berbeda dengan persepsi kualitas (perceived quality) pada merek Etude House House. Harga dari kosmetik Wardah dan Etude House berbeda. Kosmetik merek Wardah lebih terjangkau daripada merek Etude House. Selain perbedaan harga, efek jangka panjang yang dirasakan dari masing-masing produk. Beberapa konsumen merasakan tidak ada efek negatif jangka panjang, namun juga ada konsumen yang merasakan ada permasalahan di kulit wajah setelah penggunaan produk kosmetik.

Hasil uji komparatif loyalitas merek (brand loyalty) membuktikan bahwa H1 ditolak dan H0 diterima. Artinya, loyalitas merek (brand loyalty) kosmetik Wardah tidak berbeda dengan loyalitas merek (brand loyalty) pada merek Etude House. 
Kosmetik merupakan produk yang digunakan sehari-hari sehingga, konsumen akan terus membeli produk kosmetik ketika produk kosmetik mereka habis. Produk kosmetik Wardah dan Etude House merupakan pilihan merek kosmetik yang menjadi alternatif konsumen karena konsumen terbiasa dengan merek Etude House sedangkan harga produk kosmetik Wardah yang terjangkau.

Pengujian ada atau tidaknya perbedaan loyalitas merek (brand loyalty) berdasarkan jenis merek kosmetik, menghasilkan nilai signifikansi sebesar 0,187 lebih besar dari 0,05, maka H1 ditolak dan H0 diterima. Hal ini berarti loyalitas merek (brand loyalty) kosmetik wardah tidak berbeda dengan loyalitas merek (brand loyalty) pada merek Etude House. Berdasarkan perhitungan indeks, rata-rata ekuitas merek Etude House House lebih tinggi yaitu sebesar 80,2 dibandingkan merek Wardah yang sebesar 78,5.

\section{SARAN}

Untuk merek Etude House House: perlu meningkatkan upaya persepsi kualitas produknya, membuat range warna lebih banyak untuk produk BB Cream atau foundationnya. Etude House House juga dapat memperbaharui formula bahan-bahan yang digunakan agar konsumen merasa ada manfaat yang terlihat.

Untuk merek Wardah, kemasan dapat dilakukan perubahan menjadi lebih menarik dan tidak membosankan, mengatasi problem konsumen yang kurang menyukai karena dinilai produk Wardah tidak sesuai ekspektasi mereka contohnya lipstick matte Wardah yang bagi sebagian responden membuat bibir kering dan teksturnya terlalu berat. 


\section{DAFTAR PUSTAKA}

Aaker, David A. 1992. "Managing the Most Important Assets Brand quity."Planning Review 20(5):56-58. Retrieved https://www.emeraldinsight.com/doi/abs/10.1108/eb054384).

Bastian, Danny. 2014. “Analisa Pengaruh Citra Merek ( Brand Image ) Dan Kepercayaan Merek ( Brand Trust ) Terhadap Loyalitas Merek ( Brand Loyalty ) ADES PT . Ades Alfindo Putra Setia.” Jurnal ManajemenPemasaran Petra 2(1):1-9. Retrieved (http://ueu201411001.weblog.esaunggul.ac.id/wpcontent/uploads/sites/426 9/2017/03/1391-2555-1-SM.pdf).

Darmawan, Hudayah Syarifah, and Asnawati. 2016. "Perbandingan Ekuitas Merek Indomie Dan Mie Sedaap.” Jurnal Manajemen 8(2):113-35. Retrieved (http://journal.feb.unmul.ac.id/ index.php/JURNALMANAJEMEN/article/do wnload/1190/pdf.).

Ferdinand, Augusty. 2011. Metode Penelitian Manajemen. 3rd ed. Badan Penerbit Universitas Diponegoro.

Giroux, Marilyn, Frank Pons, Lionel Maltese, and Marilyn Giroux. 2017. “The Role of Perceived Brand Personality in Promotion Effectiveness and Brand Equity Development of Professional Sports Teams.” International Journal of Sports Marketing and Sponsorship 18(2):180-95. Retrieved (https://www.emeraldinsight.com/ doi/full/10.1108/IJSMS-05-2017-092).

JakPat. 2015. The Summary of Survey Result: Lokal vs Impor. Retrieved (https://blog.jakpat.net/preference-for-local-vs-imported-products-surveyreport/).

JakPat. 2016a. Brand Tracking. Retrieved (https://blog.jakpat.net/brand-trackingmake-up-product/).

JakPat.2016b. Report Cosmetics Purchasing Trends 2016. Retrieved (https://blog.jakpat.net/cosmetic-purchasing-trends-survey-report/). 
Juliana. 2016. "Pengaruh Celebrity Endorser Dan Brand Image Terhadap Purchase Intention Produk Kosmetik Etude House Pada Mahasiswa Politeknin IT \& B Medan.” POLITEKNIK IT\&B MEDAN. Retrieved (https://s3.amazonaws.com/ academia.edu.documents/49400865/PENELITIAN_JULIANA_TAHUN_ 2016.pdf?AWSAccessKeyId=AKIAIWOWYYGZ2 Y53UL3A\&Expires $=1509775782$ \&Signature=cjkAA1g896YrIDicq1N90gW odWE\%3D\&response-contentdisposition=inline\%3B

filename\%3DPENGARUH_CELEBRITY_ENDORSER _DAN_BRAND_I M.pdf).

Jung, Jaehee and Eunyoung Sung. 2008. "Consumer-Based Brand Equity Comparisons among Americans and.” Fashion Marketing and Management 12(1):24-35. Retrieved (https://www.emeraldinsight.com/doi/abs/10.1108/13612020810857925).

Kertajaya, Hermawan. 2010. Brand Operation. Erlangga.

Loureiro, Sandra. 2017. “Advertising and Country-of-Origin Images as Sources of Brand Equity and the Moderating Role of Brand Typicality.” Baltic $\begin{array}{llll}\text { Journal of } & \text { Management }\end{array}$ (https://www.emeraldinsight.com/doi/full/10.1108/BJM-11-2015-0226).

Molinillo, Sebastian, Arnold Japutra, Bang Nguyen, Cheng-hao Steve Chen, and Cheng-hao Steve Chen. 2017. "Responsible Brands VS Active Brands An Examination of Brand Personality On Brand Awareness , Brand Trust , and Brand Loyalty.” Marketing Intelligence \& Planning 35(2):166-79. Retrieved (https://www.emeraldinsight.com/doi/full/10.1108/MIP-042016-0064).

Mourad, Maha. 2011. "Brand Equity in Higher Education.” Marketing Intelligence \& Planning 29(4):403-20. Retrieved (https://www.emeraldinsight.com/doi/abs/ 10.1108/02634501111138563). 
Parengkuan, Kissi, Fatimawali, and Citraningtyas Gayatri. 2013. “Analisis Kandungan Merkuri Pada Krim Pemutih Yang Beredar Di Kota Manado.” $\begin{array}{llll}\text { Ilmiah } & \text { Farmasi } & 2 . & \text { Retrieved }\end{array}$ (http://download.portalgaruda.org/article.php?article=15419\&val=1015).

Permana, Magyar and Jony Haryanto. 2014. "Pengaruh Country of Origin, Brand Image Dan Persepsi Kualitas Terhadap Intensi Pembelian.” XVIII(3):36580. Retrieved (https://media.neliti.com/media/publications/112392-IDnone.pdf).

Rangkuti, Freddy. 2002. The Power of Brands. Badan Penerbit Universitas Diponegoro.

Rodrigues, Paula. 2016. "Perceptual and Behavioural DimensionMeasuring Brand Equity Consumer Based.” Journal of Fashion Marketing and Management: An International Journal 20(4). Retrieved (https://www.emeraldinsight.com/doi/full/10.1108/JFMM-03-2016-0019).

Romaniuk, Jenni, Samuel Wight, and Margaret Faulkner. 2016. "Brand Awareness: Revisiting an Old Metric for a New World.” Journal of $\begin{array}{llll}\text { Product } \quad \text { \& } & \text { Brand }\end{array}$ (https://www.emeraldinsight.com/doi/abs/10.1108/JPBM-06-20161242?af=R).

Santoso, Yussy and Ronnie Resdianto. 2007. "Brand Sebagai Kekuatan Perusahaan Dalam Persaingan Global.” Business \& Management 3:52-63. Retrieved (https://journal.ubm.ac.id/index.php/businessmanagement/article/view/342/329).

Stocchi, Lara and Rachel Fuller. 2017. “A Comparison of Brand Equity Strength Across Consumer Segments and Markets.” Journal of Product \& Brand Management 26(5):453-68. Retrieved (https://www.emeraldinsight.com/doi/abs/10.1108/JPBM-06-2016-1220). 
Sujarweni, Wiratna. 2015. Metodologi Penelitian Bisnis \& Ekonomi. Pustaka Baru Press.

Sukristiani, Dwi. 2014. "Pengetahuan Tentang Kosmetika Perawatan Kulit Wajah Dan Riasan Pada Mahasiswi Jurusan Kesejahteraan Keluarga Fakultas Teknik Universitas Negeri Padang).” (September). Retrieved (http://ejournal.unp.ac.id/index.php/ jhet/article/view/4325/3390).

Suyadi, Muhammad and Dahlan Fannani. 2017. “Quality Dan Brand Loyalty Terhadap Brand Equity (Survei Pada Konsumen Usia Remaja Di Kelurahan Purwantoro Kecamatan Blimbing Malang Yang Menggunakan Kartu Prabayar IM3 PT . Indosat).” 7(2). Retrieved (http://download.portalgaruda.org/article.php?article=189795 \&val=6468\& title=PENGARUH BRAND AWARENESS, BRAND ASSOCIATION, PERCEIVED QUALITY DAN BRAND LOYALTY TERHADAP BRAND EQUITY (Survei Pada Konsumen Usia Remaja Di Kelurahan Purwantoro Kecamatan Blimbing Malang Yang Menggunakan Kartu Prabayar IM3 PT.Indosat).

Veloutsou, Cleopatra, Francisco Guzmán, Cleopatra Veloutsou, and Francisco Guzmán. 2017. “The Evolution of Brand Management Thinking over the Last 25 Years as Recorded in the Journal of Product and Brand Management.” Journal of Product and Brand Management 26(1):2-12. Retrieved (https://www.emeraldinsight.com/doi/full/ 10.1108/JPBM-012017-1398).

Wulandari, Dwi. 2016. "Ramai Brand Korea Bertarung Di Pasar Kosmetik, Siapa Menang?” MIX (Marketing Communication). Retrieved (http://mix.co.id/marcomm/news-trend/ramai-brand-korea-bertarung-dipasar-kosmetik-siapa-menang). 